Polymer Journal, Vol. 39, No. 5, pp. 448-457 (2007)

(C) 2007 The Society of Polymer Science, Japan

\title{
Synthesis and Photoluminescence of Novel Organo-Soluble Polyarylates Bearing ( $N$-Carbazolyl)triphenylamine Moieties
}

\author{
Guey-Sheng Liou, ${ }^{1, \dagger}$ Sheng-Huei HsiaO, ${ }^{2}$ Huang-Ming HuANG, ${ }^{1}$ and Cha-Wen $\mathrm{CHANG}^{1}$ \\ ${ }^{1}$ Functional Polymeric Materials Research Laboratory, Department of Applied Chemistry, \\ National Chi Nan University, 1 University Road, Puli, Nantou Hsien 54561, Taiwan, Republic of China \\ ${ }^{2}$ High Performance Polymers Laboratory, Department of Chemical Engineering, Tatung University, \\ 40 Chungshan North Road, 3rd Sec., Taipei 10451, Taiwan, Republic of China
}

(Received November 13, 2006; Accepted February 16, 2007; Published March 30, 2007)

\begin{abstract}
A new series of polyarylates containing carbazolyl-substituted triphenylamine units were synthesized by direct polycondensation of 4,4'-dicarboxy-4" $-N$-carbazolyltriphenylamine with various bisphenols. All polymers were highly soluble in various common organic solvents and could afford tough, transparent, and colorless films by solution casting. These amorphous and organo-soluble polyarylates showed no significant decomposition below $470{ }^{\circ} \mathrm{C}$ in both nitrogen and air atmospheres with glass transition temperatures $\left(T_{\mathrm{g}}\right)$ ranging from 234 to $287^{\circ} \mathrm{C}$. In THF solution, these polyarylates exhibited blue photoluminescence around $464-476 \mathrm{~nm}$ with quantum yield up to $28 \%$. The photoluminescence exhibited solvent effect and was red-shifted in the polar solvent at room temperature. [doi:10.1295/polymj.PJ2006156]

KEY WORDS Polyarylates / 4,4'-Dicarboxy-4" $-N$-carbazolyltriphenylamine / Glass Transition Temperatures / Bisphenols / Photoluminescence /
\end{abstract}

It is well known that aromatic polyesters (polyarylates) possess high thermal stability and excellent mechanical properties with high visible-light transparency. ${ }^{1}$ The polyiso/terephthalate of bisphenol $\mathrm{A}$ is an example of commercially available polyarylate which has a glass transition temperature $\left(T_{\mathrm{g}}\right)$ around $195^{\circ} \mathrm{C}$ and is melt processable. However, except for this polyarylate, the high melting temperatures or softening temperatures and limited solubility in organic solvents of most polyarylates make their processing into articles difficult unless flexible spacers are included in the systems, thereby lowering the thermal stability. One of the successful approaches to increase solubility and processability with simultaneous preservation of thermal stability would be the introduction of bulky and noncoplanar structure into the polymer backbone. ${ }^{2-6}$ However, most studies have focused on their high-performance applications. There are few reports on applications using these polymers as photonic/ electronic device materials. Thus, modulation of their photophysical and electrical properties by means of a simple condensation synthetic method may be an impressive challenge in terms of new development of polymeric light-emitting diodes (PLEDs) materials.

Organic light-emitting diodes (OLEDs) devices have been the subject of recent extensive studies. They have attracted a great deal of attention in view of both fundamental and technological applications for full-color, flat-panel displays and lighting. ${ }^{7-10}$ The performance of OLEDs devices depends upon various materials functioning in specialized roles such as charge-transporting, charge-blocking, and emitting. Both small molecules and polymers have been studied for use as materials in organic luminescent devices. Triarylamines have attracted considerable interest as hole-transporting materials for use in multilayer OLEDs devices because of their low ionization potential and high hole mobility. ${ }^{11-14}$ The feasibility of using spin-coating and ink-jet-printing processes for large-area luminescent devices and the possibility of various chemical modifications (to improve emission efficiencies and allow patterning) make polymeric materials containing triarylamine units very attractive. ${ }^{15-23}$ To enhance the hole injection ability of polymeric emissive materials such as poly(1,4-phenylenevinylene)s (PPVs) and polyfluorenes (PFs), there have been several reports on PPV and PF derivatives involving hole-transporting units such as triphenylamine or carbazole groups in the emissive $\pi$-conjugated core/main chains, ${ }^{24-29}$ grafting them as side chains in a polymer, ${ }^{30-32}$ or attaching them onto the polymer chain ends or outer surface of dendritic wedges. ${ }^{33,34}$

Carbazole is another well-known hole-transporting and light emitting unit. Polymers containing carbazole moieties in the main chain or side chain have attracted much attention because of their unique properties, which allow various optoelectronic applications such as photoconductive, luminescent, and photorefractive materials. ${ }^{35,36}$ In the field of OLED, carbazole derivatives are often used as the materials for hole-transport-

${ }^{\dagger}$ To whom correspondence should be addressed (Fax: +886-49-2917956, E-mail: gsliou@ncnu.edu.tw). 
ing and light-emitting layers. Moreover, carbazole derivatives are used as layers because of their high charge mobility and thermal stability, and they show blue luminescence because of the large band gap of the improved planar biphenyl unit by the bridging nitrogen atom. ${ }^{37}$ From a structural point of view, carbazole differs from diphenylamine in its planar structure because it can be further imagined as bonded diphenylamine; the thermal stability of materials with the incorporation of carbazolyl units therefore is improved. Carbazole also can be easily functionalized at the $(3,6)-,{ }^{38-40}(2,7)-,{ }^{41}$ or N-positions ${ }^{42-44}$ and then covalently linked into polymeric systems, both in the main chain ${ }^{45-50}$ as building blocks and in the side chain as pendent groups. ${ }^{51-55}$ It is thus worthwhile to design a carbazole-based aromatic dicarboxylic acid as a starting monomer for the preparation of a new class of high-performance polyarylates with novel optoelectronic functions.

Recently, in order to obtain high- $T_{\mathrm{g}}$ hole-transporting polymers, we have reported the synthesis of soluble aromatic polyimides and polyamides bearing triphenylamine (TPA) units in the main chain based on $N, N$-bis(4-aminophenyl)- $N^{\prime}, N^{\prime}$-diphenyl-1,4-phenylenediamine $^{56}$ and $N, N$-bis(4-carboxyphenyl)- $N^{\prime}, N^{\prime}-$ diphenyl-1,4-phenylenediamine, ${ }^{57}$ respectively. Because of the incorporation of bulky, propeller-shaped TPA units along the polymer backbone, all the polymers were amorphous with high $T_{\mathrm{g}} \mathrm{s}$ and enhanced thermal stability, showed good solubility in many aprotic solvents, and good film-forming capability. In this article, we therefore synthesized a series of novel TPA-containing polyarylates with pendent carbazole groups from the dicarboxylic acid monomer, 4,4'-dicarboxy-4" $-N$-carbazolyltriphenylamine (1), and various bisphenols by direct polyesterification. The incorporation of bulky 4-( $N$-carbazolyl)triphenylamine moieties would interrupt the intermolecular interaction of the polymers and generally disturb the coplanarity of the aromatic units to reduce stacking efficiency and crystallinity. In addition, the prepared carbazole and TPA-containing polyarylates may find application in organic photoluminescent element because carbazole and TPA derivatives and polymers are reputed to be light-emitting materials. The general properties such as solubility, crystallinity, and thermal properties are reported. The electrochemical and photoluminescent properties of these polymers are also described herein.

\section{EXPERIMENTAL}

\section{Materials \\ 4,4'-Dicarboxy-4"'-( $N$-carbazolyl)triphenylamine (1) $\left(\mathrm{mp}=334-337^{\circ} \mathrm{C}\right)$ was synthesized by the sodium}

hydride-assisted condensation of $\mathrm{N}$-(4-aminophenyl)carbazole with 4-fluorobenzonitrile, followed by alkaline hydrolysis of the intermediate dinitrile compound according to a previously reported procedure. ${ }^{58}$ Carbazole (ACROS), palladium on charcoal $(\mathrm{Pd} / \mathrm{C}$; Fluka), sodium hydride (95\%; dry Aldrich), 4-fluorobenzonitrile (TCI), potassium hydroxide (TEDIA), $N, N$-dimethylacetamide (DMAc) (TEDIA), $N, N$-dimethylformamide (DMF) (ACROS), $N$-methyl-2-pyrrolidinone (NMP) (TEDIA), pyridine (Py) (TEDIA), and diphenyl chlorophosphate (DPCP) (ACROS) were used without further purification. The bisphenol monomers that include 4,4'-isopropylidenediphenol (bisphenol A; 2a) (ACROS), 9,9-bis(4-hydroxyphenyl)fluorine (2b) (TCI), phenolphthalein (2c) (Aldrich), 4,4'-dihydoxydiphenyl ether (2d) (TCI), and 2,2bis(4-hydroxyphenyl)hexafluoropropane (2e) (TCI) were purified by recrystallization. Commercially obtained anhydrous lithium chloride was dried under vacuum at $150^{\circ} \mathrm{C}$ for $10 \mathrm{~h}$. Tetrabutylammonium perchlorate (TBAP) was obtained from ACROS and recrystallized twice from ethyl acetate and then dried in vacuo prior to use.

\section{Synthesis of Polyarylates}

A typical example of polycondensation is described as follows: A solution of diphenylchlorophosphate (DPCP) $(0.69 \mathrm{~g}), \mathrm{LiCl}(0.08 \mathrm{~g})$, and pyridine $(4.0 \mathrm{~mL})$ was stirred at room temperature for $30 \mathrm{~min}$ and then added dropwise for $20 \mathrm{~min}$ to a hot solution $\left(120^{\circ} \mathrm{C}\right)$ containing $0.498 \mathrm{~g}(1.00 \mathrm{mmol})$ of 4,4'-dicarboxy-4" $(\mathrm{N}$-carbazolyl)triphenylamine (1) and $0.228 \mathrm{~g}(1.00$ mmol) of bisphenol A in pyridine $(2.0 \mathrm{~mL})$. The final solution was heated at $120^{\circ} \mathrm{C}$ for $3 \mathrm{~h}$ under stirring. The obtained polymer solution was poured slowly into $200 \mathrm{~mL}$ of water, and the white precipitate was filtered and washed with methanol. Precipitations from chloroform into methanol were carried out twice for further purification and then dried at $120^{\circ} \mathrm{C}$ under vacuum. The inherent viscosity of the polymer $\mathbf{3 a}$ was $0.34 \mathrm{dL} \mathrm{g}^{-1}$ measured at a concentration of $0.5 \mathrm{~g} \mathrm{dL}^{-1}$ in NMP at $30^{\circ} \mathrm{C}$. IR (film): $1734(\mathrm{C}=\mathrm{O}$ stretch), $1200-1300 \mathrm{~cm}^{-1}$ (C-O stretch). ANAL. Calcd for $\left(\mathrm{C}_{47} \mathrm{H}_{34} \mathrm{~N}_{2} \mathrm{O}_{4}\right)_{n}(690.78)_{n}: \mathrm{C}, 81.72 \% ; \mathrm{H}: 4.96 \%$; N: 4.06\%. Found: C, 81.06\%; H, 4.89\%; N, 4.03\%. ${ }^{1} \mathrm{H}$ NMR $\left(\mathrm{CDCl}_{3}-d, \delta, \mathrm{ppm}\right): 1.73\left(\mathrm{~s}, 3 \mathrm{H},-\mathrm{CH}_{3}\right)$, $7.14\left(\mathrm{~d}, 4 \mathrm{H}, \mathrm{H}_{\mathrm{i}}\right), 7.26-7.33\left(\mathrm{~m}, 10 \mathrm{H}, \mathrm{H}_{\mathrm{f}}+\mathrm{H}_{\mathrm{b}}+\mathrm{H}_{\mathrm{j}}\right)$, 7.40-7.48 (m, 6H, $\left.\mathrm{H}_{\mathrm{e}}+\mathrm{H}_{\mathrm{g}}+\mathrm{H}_{\mathrm{d}}\right), 7.58\left(\mathrm{~d}, 2 \mathrm{H}, \mathrm{H}_{\mathrm{c}}\right)$, 8.15-8.19 (m, 6H, $\left.\mathrm{H}_{\mathrm{h}}+\mathrm{H}_{\mathrm{a}}\right) .{ }^{13} \mathrm{C}$ NMR $\left(\mathrm{CDCl}_{3}-d, \delta\right.$, ppm): $31.0\left(-\mathrm{CH}_{3}\right), 42.6\left(\mathrm{C}^{19}\right), 109.7\left(\mathrm{C}^{10}\right), 120.1$ $\left(\mathrm{C}^{11}\right), 120.4\left(\mathrm{C}^{13}\right), 121.1\left(\mathrm{C}^{16}\right), 122.9\left(\mathrm{C}^{3}\right), 123.4$ $\left(\mathrm{C}^{14}\right), 124.1\left(\mathrm{C}^{1}\right), 126.0\left(\mathrm{C}^{12}\right), 127.4\left(\mathrm{C}^{7}\right), 128.0$ $\left(C^{17}\right), 128.3\left(C^{6}\right), 131.9\left(C^{2}\right), 134.7\left(C^{8}\right), 140.6$ $\left(C^{9}\right), 144.8\left(C^{5}\right), 148.0\left(C^{18}\right), 148.6\left(C^{4}\right), 151.3$ $\left(\mathrm{C}^{15}\right), 164.6(\mathrm{C}=\mathrm{O})$. 
The other polyarylates $\mathbf{3 b}$ to $\mathbf{3 e}$ were synthesized by an analogous procedure described as above. The NMR and elemental analysis were also measured to confirm the corresponding polymer structures.

ANAL. Calcd of polymer $3 \mathbf{b}$ for $\left(\mathrm{C}_{57} \mathrm{H}_{36} \mathrm{~N}_{2} \mathrm{O}_{4}\right)_{n}$ (812.90) ${ }_{n}$ : C, 84.22\%; H: 4.46\%; N: 3.45\%. Found: $\mathrm{C}, 83.96 \% ; \mathrm{H}, 4.39 \%$; N, 3.38\%. ${ }^{1} \mathrm{H}$ NMR $\left(\mathrm{CDCl}_{3}-\right.$ $d, \delta, \mathrm{ppm}): 7.12(\mathrm{~d}, 4 \mathrm{H}), 7.28-7.34(\mathrm{~m}, 12 \mathrm{H}), 7.37-$ $7.51(\mathrm{~m}, 10 \mathrm{H}), 7.58(\mathrm{~d}, 2 \mathrm{H}), 7.80(\mathrm{~d}, 2 \mathrm{H}), 8.15(\mathrm{~d}$, $4 \mathrm{H}), 8.16(\mathrm{~d}, 2 \mathrm{H}) .{ }^{13} \mathrm{C} \mathrm{NMR}\left(\mathrm{CDCl}_{3}-d, \delta, \mathrm{ppm}\right): 64.6$, 109.7, 120.1, 120.2, 120.4, 121.4, 122.9, 123.4, 124.0, 126.0, 126.1, 127.3, 127.7, 127.9, 128.3, 129.1, 131.8, 134.7, 140.0, 140.6, 143.2, 144.7, 149.7, 150.8, 151.2, 164.4 .

ANAL. Calcd of polymer 3c for $\left(\mathrm{C}_{52} \mathrm{H}_{32} \mathrm{~N}_{2} \mathrm{O}_{6}\right)_{n}$ (780.82) ${ }_{n}$ : C, 79.99\%; H: 4.13\%; N: 3.59\%. Found: C, 79.46\%; H, 4.09\%; N, 3.54\%. ${ }^{1} \mathrm{H}$ NMR $\left(\mathrm{CDCl}_{3}-d\right.$, $\delta$, ppm): $7.22(\mathrm{~d}, 4 \mathrm{H}), 7.28-7.31(\mathrm{~m}, 6 \mathrm{H}), 7.38-7.50$ (m, 10H), 7.56-7.61 (m, 4H), $7.72(\mathrm{t}, 1 \mathrm{H}), 7.96(\mathrm{~d}$, $1 \mathrm{H}), 8.14-8.17(\mathrm{~m}, 6 \mathrm{H}) .{ }^{13} \mathrm{C} \mathrm{NMR}\left(\mathrm{CDCl}_{3}-d, \delta, \mathrm{ppm}\right)$ : 90.8, 109.6, 120.1, 120.4, 121.8, 122.9, 123.4, 123.6, 124.1, 125.4, 126.0, 126.1, 127.4, 128.3, 128.4, 129.6, 131.9, 134.4, 134.8, 138.1, 140.6, 144.6, 151.1, 151.3,

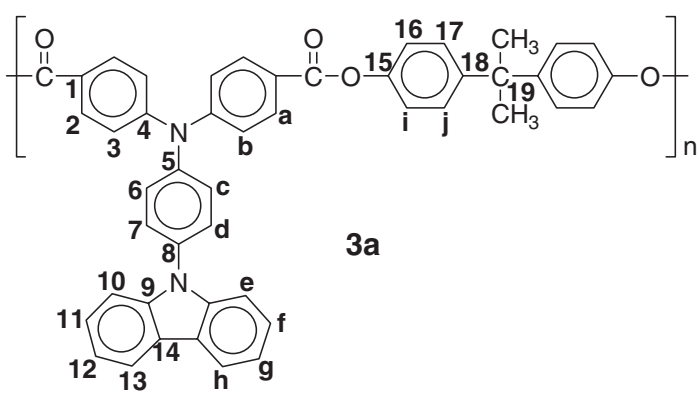

\section{Preparation of the Polyarylate Films}

A polymer solution was made by the dissolution of about $0.5 \mathrm{~g}$ of the polyarylate sample in $10 \mathrm{~mL}$ of chloroform. The homogeneous solution was poured into an 8-cm-diameter glass Petri dish, which was placed in a room temperature overnight for slow release of the solvent. Then the obtained semidried polymer film was stripped off from the glass substrate and further dried in oven at $120^{\circ} \mathrm{C}$ for $3 \mathrm{~h}$. The obtained films were about 50-70 $\mu \mathrm{m}$ thick and were used for X-ray diffraction measurements, solubility tests, thermal and optical analyses.

\section{Measurements}

Infrared spectra were recorded on a PerkinElmer RXI FT-IR spectrometer. Elemental analyses were run in an Elementar VarioEL-III. ${ }^{1} \mathrm{H}$ and ${ }^{13} \mathrm{C}$ NMR nuclear magnetic resonance (NMR) spectra were measured on a Bruker AV-300 FT-NMR system. The inherent viscosities were determined at $0.5 \mathrm{~g} / \mathrm{dL}$ concentration using Tamson TV-2000 viscometer at
151.6, 164.2, 169.4.

ANAL. Calcd of polymer 3d for $\left(\mathrm{C}_{44} \mathrm{H}_{28} \mathrm{~N}_{2} \mathrm{O}_{5}\right)_{n}$ $(664.70)_{n}$ : C, $79.50 \%$; H: 4.25\%; N: 4.21\%. Found: C, $78.96 \% ; \mathrm{H}, 4.19 \% ; \mathrm{N}, 4.18 \% .{ }^{1} \mathrm{H}$ NMR $\left(\mathrm{CDCl}_{3}-d\right.$, $\delta$, ppm): $7.11\left(\mathrm{~d}, 4 \mathrm{H}, \mathrm{H}_{\mathrm{i}}\right), 7.21\left(\mathrm{~d}, 4 \mathrm{H}, \mathrm{H}_{\mathrm{j}}\right), 7.30-7.34$ $\left(\mathrm{m}, 6 \mathrm{H}, \mathrm{H}_{\mathrm{b}}+\mathrm{H}_{\mathrm{f}}\right), 7.41-7.52\left(\mathrm{~m}, 6 \mathrm{H}, \mathrm{H}_{\mathrm{d}}+\mathrm{H}_{\mathrm{g}}+\right.$ $\left.\mathrm{H}_{\mathrm{e}}\right), 7.60\left(\mathrm{~d}, 2 \mathrm{H}, \mathrm{H}_{\mathrm{c}}\right), 8.15-8.20\left(\mathrm{~m}, 6 \mathrm{H}, \mathrm{H}_{\mathrm{h}}+\mathrm{H}_{\mathrm{a}}\right)$. ${ }^{13} \mathrm{C}$ NMR $\left(\mathrm{CDCl}_{3}-d, \delta, \mathrm{ppm}\right): 109.7\left(\mathrm{C}^{10}\right), 119.6$ $\left(\mathrm{C}^{16}\right), 120.2\left(\mathrm{C}^{11}\right), 120.4\left(\mathrm{C}^{13}\right), 122.9\left(\mathrm{C}^{17}\right), 122.9$ $\left(\mathrm{C}^{3}\right), 123.4\left(\mathrm{C}^{14}\right), 123.9\left(\mathrm{C}^{1}\right), 126.0\left(\mathrm{C}^{12}\right), 127.4$ $\left(\mathrm{C}^{7}\right), 128.4\left(\mathrm{C}^{6}\right), 131.9\left(\mathrm{C}^{2}\right), 134.8\left(\mathrm{C}^{8}\right), 140.6\left(\mathrm{C}^{9}\right)$, $144.7\left(\mathrm{C}^{5}\right), 146.5\left(\mathrm{C}^{18}\right), 151.3\left(\mathrm{C}^{4}\right), 154.8\left(\mathrm{C}^{15}\right)$, $164.7(\mathrm{C}=\mathrm{O})$.

ANAL. Calcd of polymer 3e for $\left(\mathrm{C}_{47} \mathrm{H}_{28} \mathrm{~F}_{6} \mathrm{~N}_{2} \mathrm{O}_{4}\right)_{n}$ (798.73) $)_{n}$ : C, 70.68\%; H: 3.53\%; N: 3.51\%. Found: $\mathrm{C}, 70.19 \%$; $\mathrm{H}, 3.49 \%$; N, 3.45\%. ${ }^{1} \mathrm{H}$ NMR $\left(\mathrm{CDCl}_{3}-\right.$ $d, \delta, \mathrm{ppm}): 7.30-7.36(\mathrm{~m}, 10 \mathrm{H}), 7.43-7.47(\mathrm{~m}, 4 \mathrm{H})$, 7.49-7.56 (m, 6H), $7.62(\mathrm{~d}, 2 \mathrm{H}), 8.17-8.22(\mathrm{~m}, 6 \mathrm{H})$. ${ }^{13} \mathrm{C}$ NMR $\left(\mathrm{CDCl}_{3}-d, \delta, \mathrm{ppm}\right): 64.0,109.6,120.2$, 120.4, 121.6, 122.9, 123.5, 123.6, 124.1, 126.0, 127.5, 128.4, 130.6, 131.5, 132.0, 134.9, 140.6, 144.6, 151.4, $151.4,164.1$.

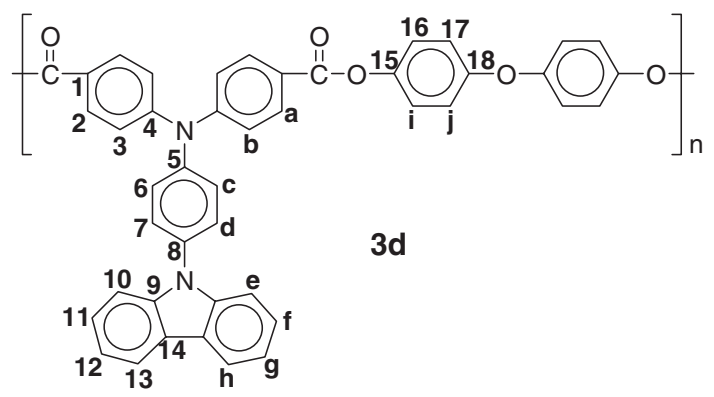

$30^{\circ} \mathrm{C}$. Gel permeation chromatography (GPC) was carried out on a Waters chromatography unit interfaced with a Waters 2410 refractive index detector. Two Waters $5 \mu \mathrm{m}$ Styragel HR-2 and HR-4 columns $(7.8 \mathrm{~mm}$ I.D. $\times 300 \mathrm{~mm})$ connected in series were used with tetrahydrofuran (THF) as the eluent at a flow rate of $1 \mathrm{~mL} \mathrm{~min}^{-1}$ and were calibrated with narrow polystyrene standards. Wide-angle X-ray diffraction (WAXD) measurements were performed at room temperature $\left(c a .25^{\circ} \mathrm{C}\right)$ on a Shimadzu XRD-7000 $\mathrm{X}$-ray diffractometer $(40 \mathrm{kV}, 20 \mathrm{~mA})$ with a graphite monochromator, using $\mathrm{Ni}$-filtered $\mathrm{Cu}-\mathrm{K} \alpha$ radiation. The scanning rate was $2^{\circ} \mathrm{min}^{-1}$ over a range of $2 \theta=$ $10-40^{\circ}$. Thermogravimetric analysis (TGA) was conducted with a PerkinElmer Pyris 1 TGA. Experiments were carried out on approximately $6-8 \mathrm{mg}$ film samples heated in flowing nitrogen or air (flow rate $=40$ $\mathrm{cm}^{3} \mathrm{~min}^{-1}$ ) at a heating rate of $20^{\circ} \mathrm{C} / \mathrm{min}$. Differential scanning calorimetry (DSC) analyses were performed on a PerkinElmer Pyris Diamond DSC at a scan rate of $20^{\circ} \mathrm{C} / \mathrm{min}$ in flowing nitrogen $(20$ 
$\mathrm{cm}^{3} \min ^{-1}$ ). Thermomechanical analysis (TMA) was conducted with a PerkinElmer TMA 7 instrument. The TMA experiments were conducted at a scan rate of $10^{\circ} \mathrm{C} / \mathrm{min}$ with a penetration probe $1.0 \mathrm{~mm}$ in diameter under an applied constant load of $50 \mathrm{mN}$. Softening temperatures $\left(T_{\mathrm{s}}\right)$ were taken as the onset temperatures of probe displacement on the TMA traces. Electrochemistry was performed with a CHI 611B electrochemical analyzer. Voltammograms are presented with the positive potential pointing to the left and with increasing anodic currents pointing downwards. Cyclic voltammetry was conducted with the use of a three-electrode cell in which ITO (polymer films area about $0.7 \mathrm{~cm} \times 0.5 \mathrm{~cm}$ ) was used as a working electrode. A platinum wire was used as an auxiliary electrode. All cell potentials were taken with the use of a home-made $\mathrm{Ag} / \mathrm{AgCl}, \mathrm{KCl}$ (sat.) reference electrode. Ultraviolet-visible (UV-Vis) spectra of the polymer films were recorded on a Varian Cary 50 Probe spectrometer. Photoluminescence spectra were measured with a Jasco FP-6300 spectrofluorometer. The fluorescence quantum yields $\left(\Phi_{\mathrm{PL}}\right)$ of polymer solution were determined in THF against quinine sulfate (ACROS) in $1 \mathrm{~N} \mathrm{H}_{2} \mathrm{SO}_{4}$ (aq) as the standard $\left(\Phi_{\mathrm{PL}}=0.546\right)$. All corrected fluorescence excitation spectra were found to be equivalent to their respective absorption spectra.

\section{RESULTS AND DISCUSSION}

\section{Polymer Synthesis}

A series of new polyarylates $\mathbf{3 a}-\mathbf{3 e}$ with 4 - $(N$-carbazolyl)triphenylamine units were prepared from the direct polycondensation reactions of dicarboxylic acid monomer 1 and bisphenols 2a-2e by using DPCP and pyridine as condensing agents (Scheme 1) ${ }^{59}$ All the polymerizations proceeded homogeneously throughout the reaction and afforded clear, moderately high

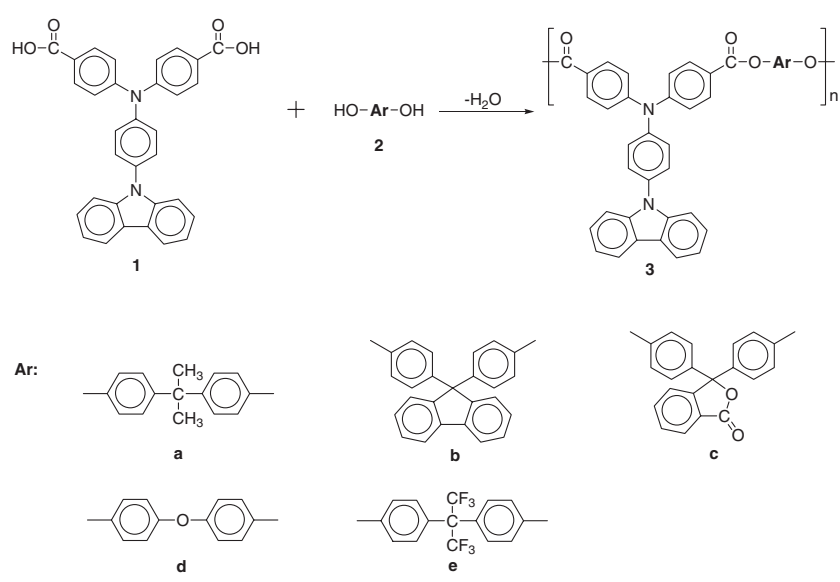

Scheme 1. Synthesis of polyarylates.
Table I. Inherent viscosity and average molecular weights ${ }^{\mathrm{a}}$ of polyarylates

\begin{tabular}{ccccc}
\hline $\begin{array}{c}\text { Polymer } \\
\text { code }\end{array}$ & $\begin{array}{c}\eta_{\text {inh }}{ }^{\mathrm{b}} \\
\left(\mathrm{dL} \mathrm{g}^{-1}\right)\end{array}$ & $M_{\mathrm{w}}$ & $M_{\mathrm{n}}$ & PDI \\
\hline 3a & 0.34 & 29500 & 15000 & 1.97 \\
3b & 0.42 & 36000 & 16500 & 2.18 \\
3c & 0.38 & 31500 & 15000 & 2.10 \\
3d & 0.55 & 43000 & 22000 & 1.95 \\
3e & 0.31 & 33500 & 17000 & 1.97 \\
\hline
\end{tabular}

${ }^{\text {a }}$ Relative to polystyrene standards, using THF as the eluent. ${ }^{\mathrm{b}}$ Measured at a polymer concentration of $0.5 \mathrm{~g} / \mathrm{dL}$ in NMP at $30^{\circ} \mathrm{C}$.

viscous polymer solutions. The polymers could be precipitated in a tough, fiber-like form when the resulting polymer solutions were slowly poured with stirring into methanol. These polyarylates were obtained in almost quantitative yields with inherent values in the range of $0.31-0.55 \mathrm{dL} \mathrm{g}^{-1}$ (Table I). Their weight-average molecular weights $\left(M_{\mathrm{w}}\right)$, numberaverage molecular weights $\left(M_{\mathrm{n}}\right)$, and polydispersity index (PDI) were recorded in the range of 2950043000, 15000-22000, and 1.95-2.18, respectively, relative to polystyrene standards (Table I). The elemental analysis data of the polyarylates were generally in good agreement with the proposed structures for hydrogen and nitrogen, while the carbon analysis data were slightly lower than the theoretical values, a phenomenon common to high-temperature polymers. The FT-IR spectra of diacid monomer 1 and polyarylate 3d are shown in Figure 1. The monomer $\mathbf{1}$ exhibited a broad and strong peak in the range of 3000-3500 $\mathrm{cm}^{-1}$, due to the carboxylic acid OH groups. However, the strong $\mathrm{OH}$ peak disappeared in the IR spectra of polyarylate 3d. The characteristic absorptions of ester group appear around $1734 \mathrm{~cm}^{-1}(\mathrm{C}=\mathrm{O}$ stretch-

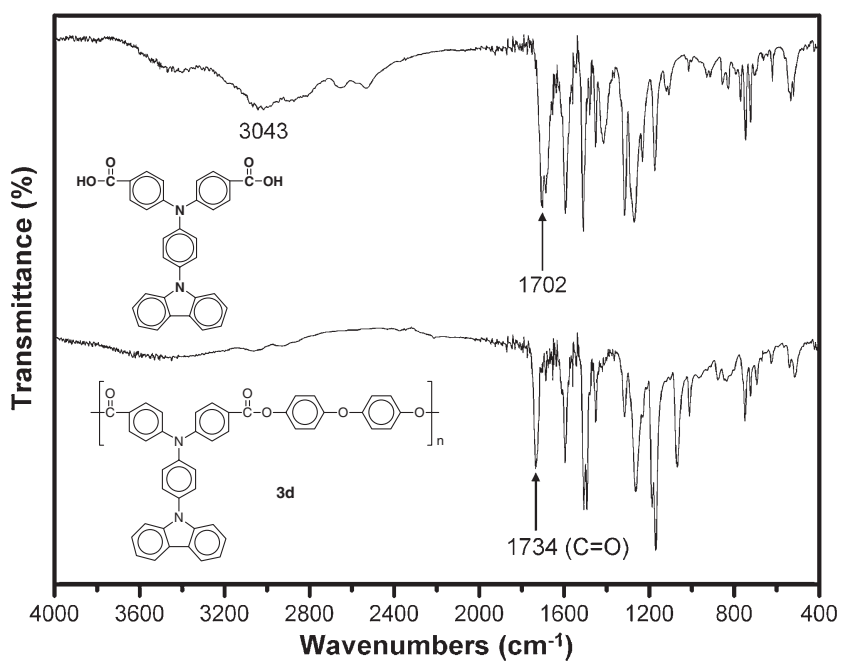

Figure 1. IR spectra of monomer and polyarylate 3d. 

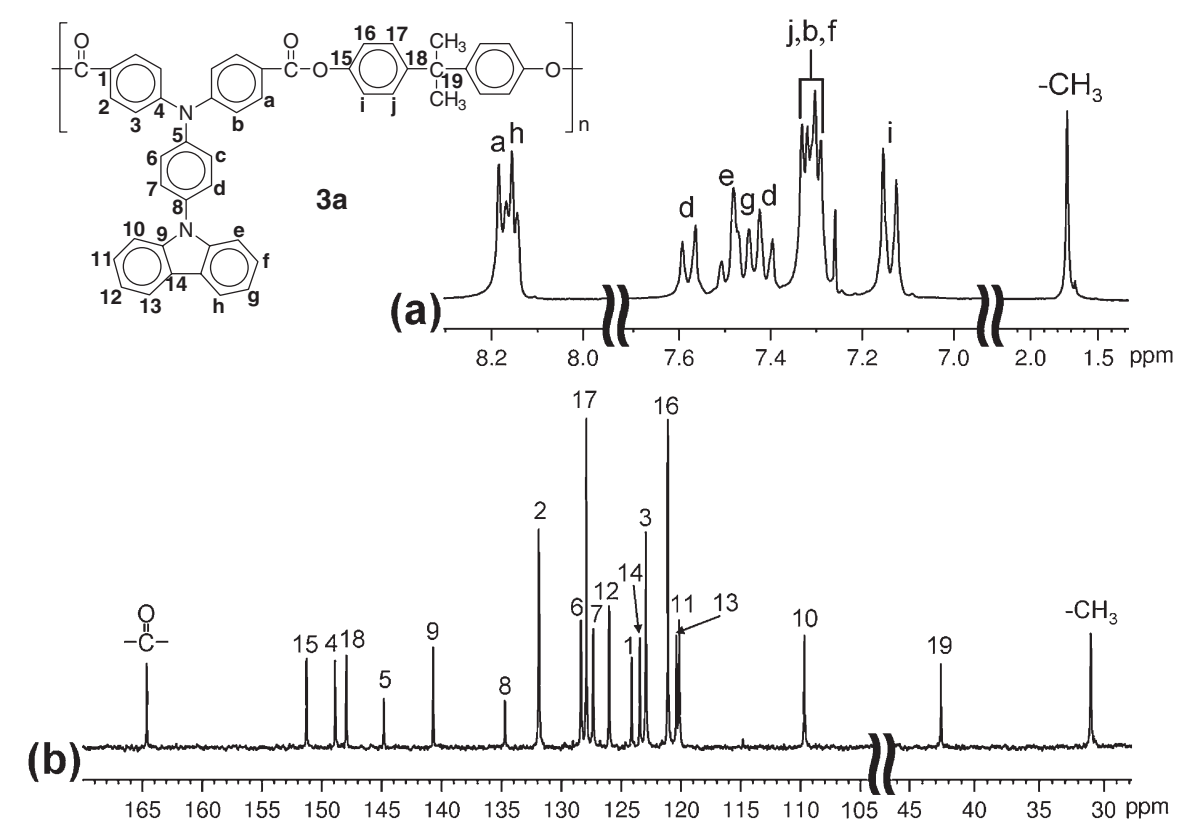

Figure 2. (a) ${ }^{1} \mathrm{H}$ NMR and (b) ${ }^{13} \mathrm{C}$ NMR spectra of polyarylate 3a in chloroform- $d$.

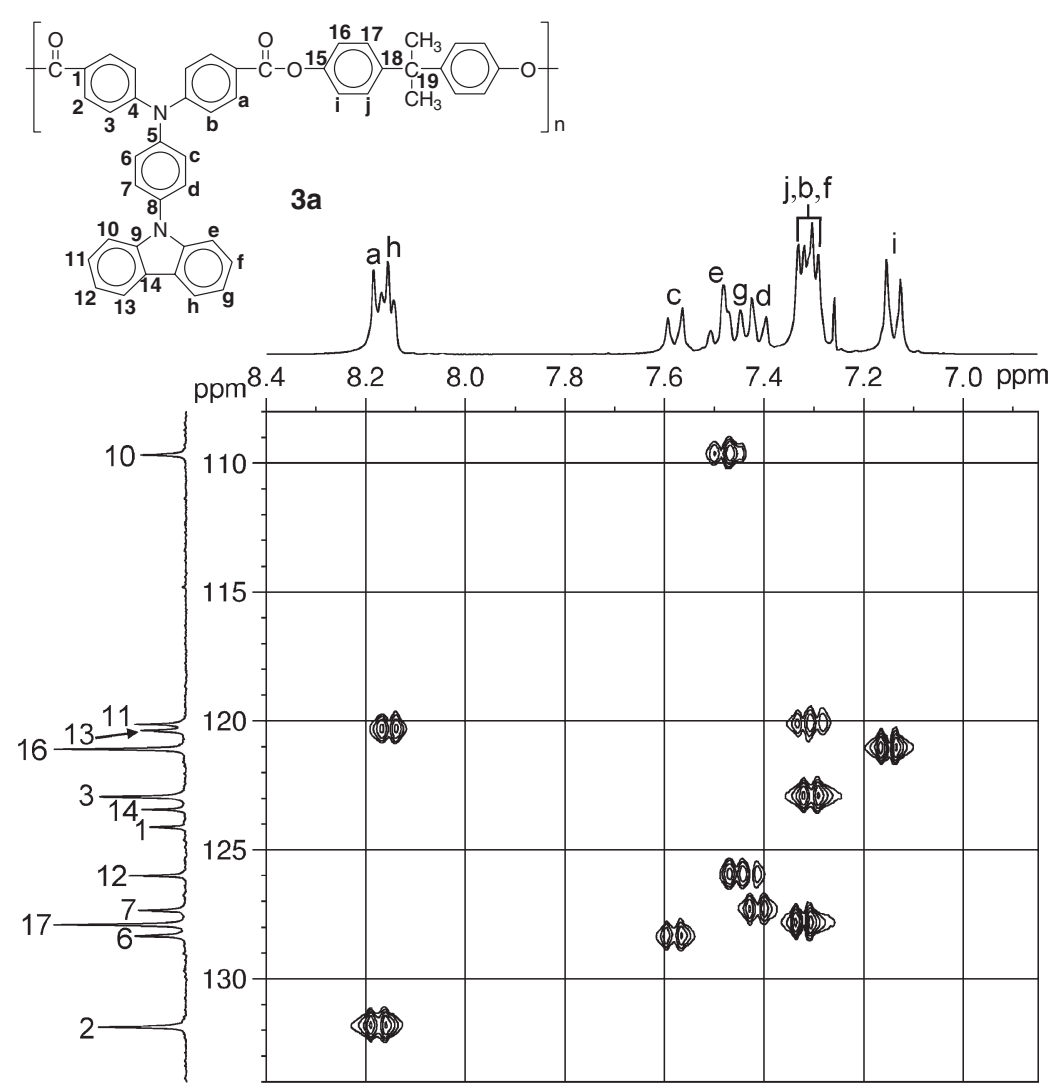

Figure 3. Aromatic region of the C-H HMQC spectrum of polyarylate 3a in chloroform- $d$.

ing) and in the region of $1200-1300 \mathrm{~cm}^{-1}(\mathrm{C}-\mathrm{O}-\mathrm{C}$ stretching). Figure 2 shows a typical set of ${ }^{1} \mathrm{H}$ and ${ }^{13} \mathrm{C}$ NMR spectra of polyarylate $\mathbf{3 a}$ in chloroform- $d$. There are 21 resonance signals in the ${ }^{13} \mathrm{C}$ NMR spectrum of polyarylate 3a due to one carbonyl carbon, 18 aromatic carbons, and two aliphatic carbons. In the aromatic region, eight resonance peaks at 151.3, $148.9,147.9,144.8,140.6,134.7,124.1$, and 123.4 are peculiar to quaternary carbons. The other aromatic ${ }^{13} \mathrm{C}$ signals are well connected with the corresponding protons as shown in the $\mathrm{C}-\mathrm{H}$ HMQC spectrum (Figure 3). 
Table II. Solubility of polyarylates

\begin{tabular}{ccccccccc}
\hline \multirow{2}{*}{$\begin{array}{c}\text { Polymer } \\
\text { code }\end{array}$} & \multicolumn{7}{c}{ Solubility $^{\mathrm{a}}$} \\
\cline { 2 - 9 } & NMP & DMAc & DMF & $m$-Cresol & THF & CHCl $_{3}$ & Toluene & MeCN \\
\hline 3a & ++ & ++ & ++ & + & ++ & ++ & \pm & - \\
3b & ++ & ++ & + & + & ++ & ++ & \pm & - \\
3c & ++ & ++ & ++ & + & ++ & ++ & \pm & - \\
3d & ++ & + & \pm & + & ++ & ++ & \pm & - \\
3e & ++ & ++ & ++ & + & ++ & ++ & ++ & - \\
\hline
\end{tabular}

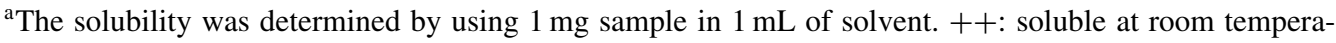
ture; + : soluble on heating; \pm : partial soluble or swelling on heating; - : insoluble even on heating.

Table III. Thermal properties of polyarylates ${ }^{\mathrm{a}}$

\begin{tabular}{cccccccc}
\hline \multirow{2}{*}{$\begin{array}{c}\text { Polymer } \\
\text { code }\end{array}$} & $T_{\mathrm{g}}\left({ }^{\circ} \mathrm{C}\right)^{\mathrm{b}}$ & $T_{\mathrm{s}}\left({ }^{\circ} \mathrm{C}\right)^{\mathrm{c}}$ & \multicolumn{2}{c}{$\begin{array}{c}T_{\mathrm{d}} \text { at } 5 \% \text { weight } \\
\text { loss }\left({ }^{\circ} \mathrm{C}\right)^{\mathrm{d}}\end{array}$} & $\begin{array}{c}T_{\mathrm{d}} \text { at } 10 \% \text { weight } \\
\text { loss }\left({ }^{\circ} \mathrm{C}\right)^{\mathrm{d}}\end{array}$ & $\begin{array}{c}\text { Char yield } \\
(\text { wt \% })^{\mathrm{e}}\end{array}$ \\
\cline { 3 - 6 } & & & $\mathrm{N}_{2}$ & Air & $\mathrm{N}_{2}$ & Air & \\
\hline 3a & 236 & 226 & 475 & 470 & 495 & 490 & 43 \\
3b & 285 & 276 & 485 & 475 & 510 & 510 & 58 \\
3c & 287 & 273 & 490 & 485 & 500 & 500 & 64 \\
3d & 234 & 224 & 505 & 495 & 525 & 520 & 56 \\
3e & 253 & 242 & 495 & 490 & 505 & 500 & 60 \\
\hline
\end{tabular}

${ }^{\mathrm{a}}$ The polymer film samples were heated at $200^{\circ} \mathrm{C}$ for $1 \mathrm{~h}$ prior to all the thermal analyses. ${ }^{\mathrm{b}}$ Midpoint temperature of baseline shift on the second DSC heating trace (rate $20^{\circ} \mathrm{C} \mathrm{min}^{-1}$ ) of the sample after quenching from $400{ }^{\circ} \mathrm{C}$. ${ }^{\mathrm{c}}$ Softening temperature measured by TMA with a constant applied of $10 \mathrm{mN}$ at a heating rate of $10^{\circ} \mathrm{C} \mathrm{min}{ }^{-1}$. ${ }^{\mathrm{d}}$ Decomposition temperature, recorded via TGA at a heating rate of $20^{\circ} \mathrm{C} \mathrm{min}^{-1}$ and a gas-flow rate of $30 \mathrm{~cm}^{3} \mathrm{~min}^{-1}$. ${ }^{e}$ Residual weight percentage at $800^{\circ} \mathrm{C}$ in nitrogen.

\section{Basic Characterization}

Table II shows the qualitative solubility of the polyarylates in various solvents. All the polymers were readily dissolved in common solvents such as NMP, DMAc, THF, and chloroform. This may be due to the existence of the propeller-shaped TPA core and bulky pendent carbazole group in the repeat unit to prevent close chain-packing and allow solvent molecules to diffuse into the polymer chains. Thus, all these polymers can be processed from solvents to afford flexible and tough films via solution casting. The wide-angle X-ray diffraction of these polyarylates (Figure 4) exhibited typically amorphous patterns owing to the presence of the bulky groups. Thus, the amorphous nature of these polymers was reflected in their excellent solubility. The excellent solubility makes these polyarylates potential candidates for practical applications in spin- or dip-coating processes.

The thermal behaviors of the polyarylates were evaluated by means of TGA, DSC, and TMA. The results are summarized in Table III. Typical TGA curves for polyarylate 3e are reproduced in Figure 5. All of the polyarylates exhibited a similar TGA pattern with no significant weight loss below $470{ }^{\circ} \mathrm{C}$ both in air and nitrogen atmosphere. The $10 \%$ weight-loss temperatures of the polyarylates in nitrogen and air were recorded in the range of 495-525 and 490-

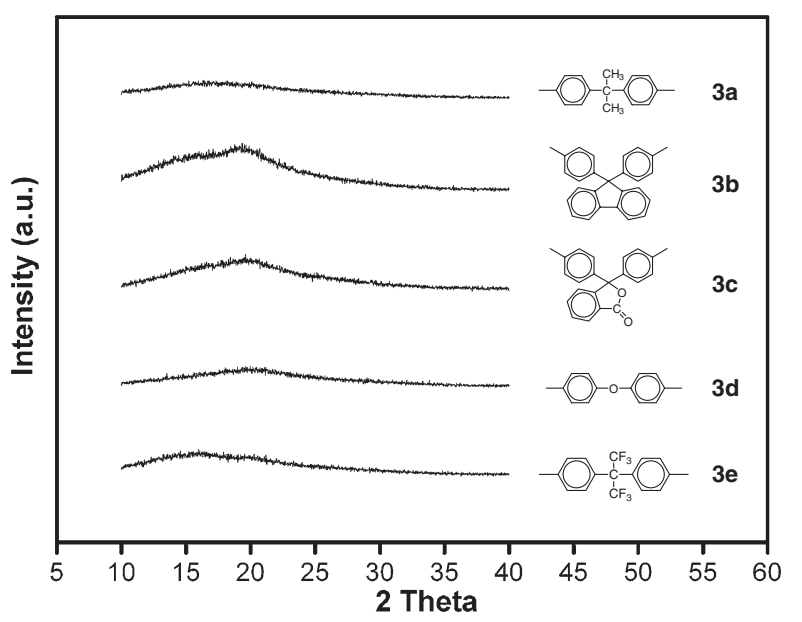

Figure 4. WAXD patterns of polyarylate films.

$520^{\circ} \mathrm{C}$, respectively. The amount of carbonized residue (char yield) of these polymers in nitrogen atmosphere was more than $40 \%$ at $800^{\circ} \mathrm{C}$. The high char yields of these polymers can be ascribed to their high aromatic content. This outstanding thermal stability also renders advantages in various applications. The glass-transition temperatures $\left(T_{\mathrm{g}}\right)$, defined by the midpoint of the baseline shift, of polymer $\mathbf{3 a}-\mathbf{3 e}$ were observed in the range of $234-287^{\circ} \mathrm{C}$, relative to the structure of bisphenol components, and decreased 


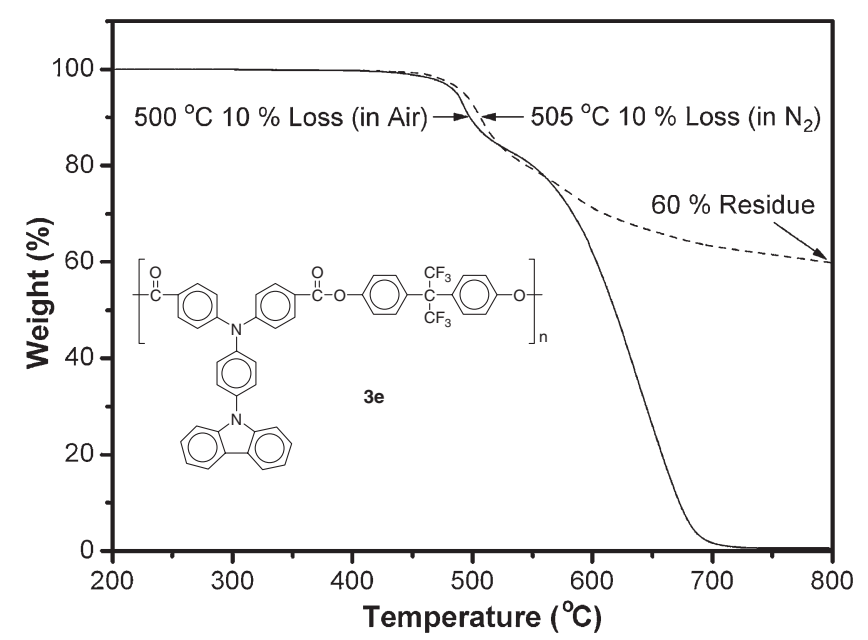

Figure 5. TGA thermograms of polyarylate $\mathbf{3 e}$ at a scan rate of $20{ }^{\circ} \mathrm{C} \mathrm{min}-1$.

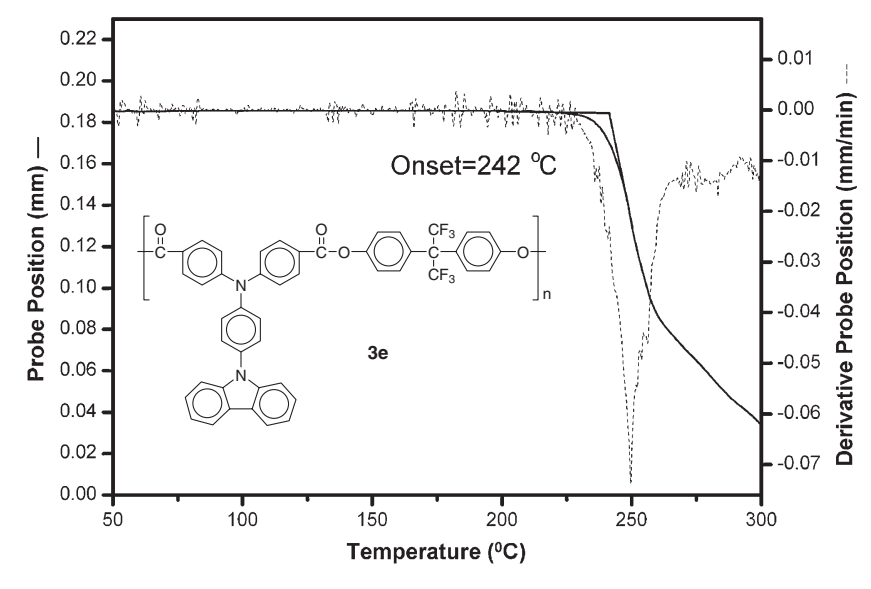

Figure 6. TMA curve of polyarylate $3 \mathbf{e}$ with a heating rate of $10{ }^{\circ} \mathrm{C} \mathrm{min}^{-1}$.

Table IV. Optical and electrochemical properties of polyarylates

\begin{tabular}{|c|c|c|c|c|c|c|c|c|c|c|c|}
\hline \multirow{3}{*}{ Index } & \multicolumn{3}{|c|}{ Solution $\lambda(\mathrm{nm})^{\mathrm{a}}$} & \multicolumn{4}{|c|}{ Film $\lambda(\mathrm{nm})$} & \multirow{3}{*}{$\begin{array}{l}\text { Oxidation (V) } \\
\text { (vs. } \mathrm{Ag} / \mathrm{AgCl} \\
\left.\text { in } \mathrm{CH}_{3} \mathrm{CN}\right) \\
E_{\text {onset }}\end{array}$} & \multirow{3}{*}{$\begin{array}{l}E_{\mathrm{g}} \mathrm{e}^{\mathrm{e}} \\
(\mathrm{eV})\end{array}$} & \multirow{3}{*}{$\begin{array}{c}\mathrm{HOMO}^{\mathrm{f}} \\
(\mathrm{eV})\end{array}$} & \multirow{3}{*}{$\begin{array}{c}\mathrm{LUMO}^{\mathrm{s}} \\
(\mathrm{eV})\end{array}$} \\
\hline & \multirow{2}{*}{$\begin{array}{l}\text { Abs } \\
\max \end{array}$} & \multirow{2}{*}{$\begin{array}{c}\mathrm{PL} \\
\max ^{b}\end{array}$} & \multirow{2}{*}{$\begin{array}{l}\Phi_{\mathrm{PL}} \\
(\%)^{\mathrm{c}} \\
\end{array}$} & \multirow{2}{*}{$\lambda_{0}{ }^{\mathrm{d}}$} & \multirow{2}{*}{$\begin{array}{l}\text { Abs } \\
\max \end{array}$} & \multirow{2}{*}{$\begin{array}{l}\text { Abs } \\
\text { onset }\end{array}$} & \multirow{2}{*}{$\begin{array}{c}\mathrm{PL} \\
\max ^{b}\end{array}$} & & & & \\
\hline & & & & & & & & & & & \\
\hline $3 \mathbf{a}$ & 342 & 464 & 22.1 & 409 & 346 & 398 & 462 & 1.01 & 3.12 & 5.33 & 2.21 \\
\hline $3 b$ & 342 & 465 & 25.0 & 412 & 346 & 404 & 464 & 0.99 & 3.07 & 5.31 & 2.24 \\
\hline $3 c$ & 342 & 472 & 22.0 & 411 & 345 & 408 & 473 & 1.02 & 3.04 & 5.34 & 2.30 \\
\hline $3 d$ & 342 & 467 & 28.3 & 409 & 346 & 410 & 464 & 1.00 & 3.02 & 5.32 & 2.30 \\
\hline $3 e$ & 342 & 476 & 20.0 & 411 & 343 & 407 & 468 & 0.98 & 3.05 & 5.30 & 2.25 \\
\hline
\end{tabular}

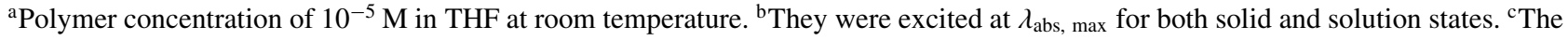
quantum yield in dilute solution was calculated in an integrating sphere with quinine sulfate as the standard $\left(\Phi_{\mathrm{F}}=0.546\right)$. ${ }^{\mathrm{d}}$ The cutoff wavelengths from the UV-Vis transmission spectra of polymer films. (thickness: $1-3 \mu \mathrm{m}$ ) ${ }^{\mathrm{e}}$ The data were calculated by the equation: gap $=1240 / \lambda_{\text {onset }}$ of polymer film. ${ }^{\mathrm{f}}$ The HOMO energy levels were calculated from cyclic voltammetry and were referenced to ferrocene $(4.8 \mathrm{eV}) .{ }^{\mathrm{g}} \mathrm{LUMO}=\mathrm{HOMO}-$ gap.

with decreasing rigidity and symmetry of the polymer backbone. In addition, polymers $\mathbf{3 b}$ and $\mathbf{3 c}$ containing a bulky group in the bisphenol components had the higher $T_{\mathrm{g}}$ values. All the polymers indicated no clear melting endotherms up to the decomposition temperatures on the DSC thermograms. This result also supports the amorphous nature of these polymers. The $T_{\mathrm{S}}$ values measured by TMA are also listed in Table III, and they were observed in the range of $224-276^{\circ} \mathrm{C}$. They are generally comparable to the $T_{\mathrm{g}}$ values obtained by the DSC technique. A typical TMA thermogram for polyarylate 3e is illustrated in Figure 6. There is a large window between $T_{\mathrm{g}}$ or $T_{\mathrm{s}}$ and the decomposition temperature of each polymer, which could also be advantageous in the processing of these polymers by the thermoforming technique. It is evident that the presence of propeller-like TPA units and bulky pendent carbazole groups hinders close peaking of the polymer chains and suppresses their crystallizability.

\section{Optical Properties}

The polymers containing carbazolyl-substituted TPA segments along the main chain exhibited optical properties of primary importance for our study. These polyarylates were investigated by UV-Vis and photoluminescence spectroscopy, and the results are summarized in Table IV. Polymers 3a-3e exhibited maximum UV-Vis absorption bands at $342-346 \mathrm{~nm}$ both in THF solution and film state, assignable to the $\pi$ $\pi^{*}$ transition resulting from the conjugation between the aromatic rings and nitrogen atom that combines the characteristic $\pi-\pi^{*}$ transition of carbazole chromophore. Figure 7 exhibits UV-Vis absorption and photoluminescence spectra of typical polyarylates 3a and $3 \mathbf{e}$ in THF solution (Conc.: $10^{-5} \mathrm{~mol} / \mathrm{L}$ ). The maximum photoluminescence (PL) intensity of the polymer solutions in THF appeared around 464-476 $\mathrm{nm}$, which corresponds to the blue region. The photoluminescence of polyarylates in solution and as thin films by UV irradiation $(365 \mathrm{~nm})$ are also showed in 


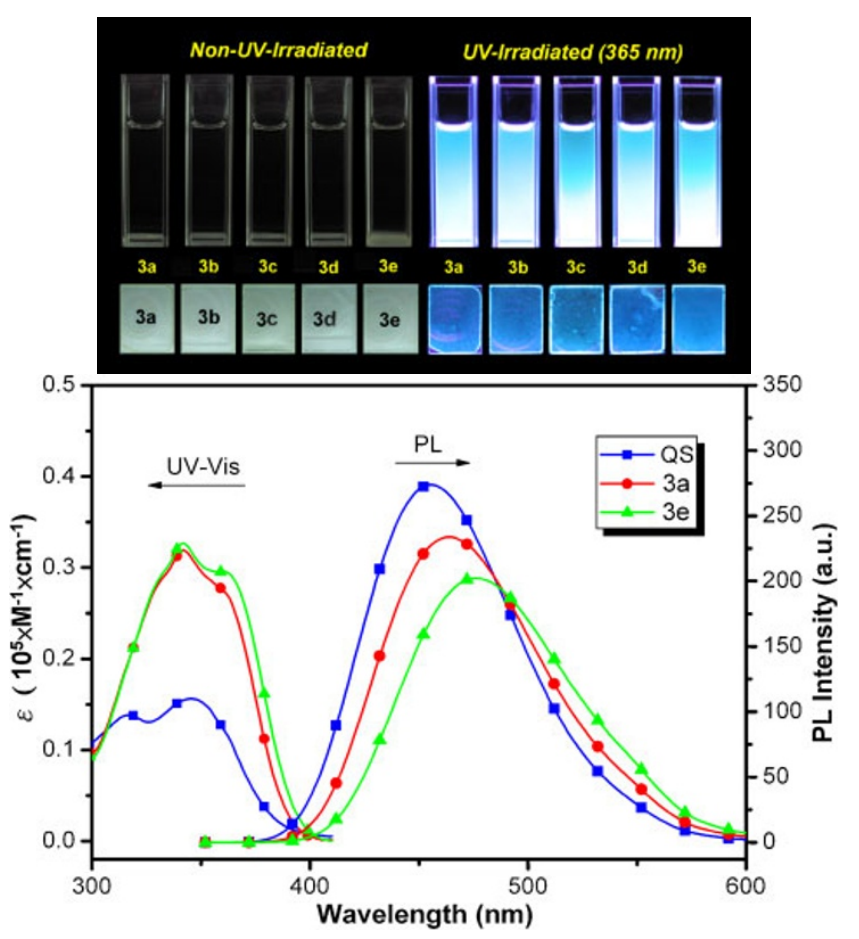

Figure 7. UV-Vis absorption and PL spectra of polyarylates in THF solution $\left(10^{-5} \mathrm{M}\right)$. Quinine sulfate (QS) dissolved in $1 \mathrm{~N}$ $\mathrm{H}_{2} \mathrm{SO}_{4}$ (aq) $\left(10^{-5} \mathrm{M}\right)$ as the standard. $\left(\Phi_{\mathrm{PL}}=0.546\right)$. Photographs show the appearance of polyarylates in THF solution $\left(10^{-5} \mathrm{M}\right)$ and as thin films (thickness: $1-3 \mu \mathrm{m}$ ) before and after exposure to a standard laboratory UV lamp (Excited at $365 \mathrm{~nm}$ ).

Figure 7. In addition, the absorption and PL spectra of the solutions of polyarylate $\mathbf{3 e}$ in various solvents, as well as its solid thin film are illustrated in Figure 8, and the key optical data of the solutions of polymer $\mathbf{3 e}$ are summarized in Table V. It is interesting to note that the PL emission of polymer $\mathbf{3 e}$ in NMP is redshifted compared to that of its thin solid film. The maximum PL intensity of the solutions of polymer 3e in NMP, chloroform, THF, and toluene solution, and its solid-state thin film appeared at 501, 481, 476,447 , and $468 \mathrm{~nm}$, respectively. The wavelength of emission maxima increased dramatically as the medium changing from less polar toluene to highly polar NMP. This phenomenon maybe could be attributed to the intramolecular charge-transfer results in the solvatochromic shifts. Generally, solvation should increase the interaction between polymer chain and solvent, which may consume certain excitation energy and lead to increase on the emission wavelength. By assuming there is no major difference on the absorption efficiency, we could expect a higher emission intensity and quantum yield for $\mathbf{3 e}$ in toluene (21.9\%) than in NMP (2.4\%) as shown in Table IV. The solvatochromic shifts of the emission spectra are much larger than those of absorption spectra, implying that the excitedstate energy levels are influenced more than those in

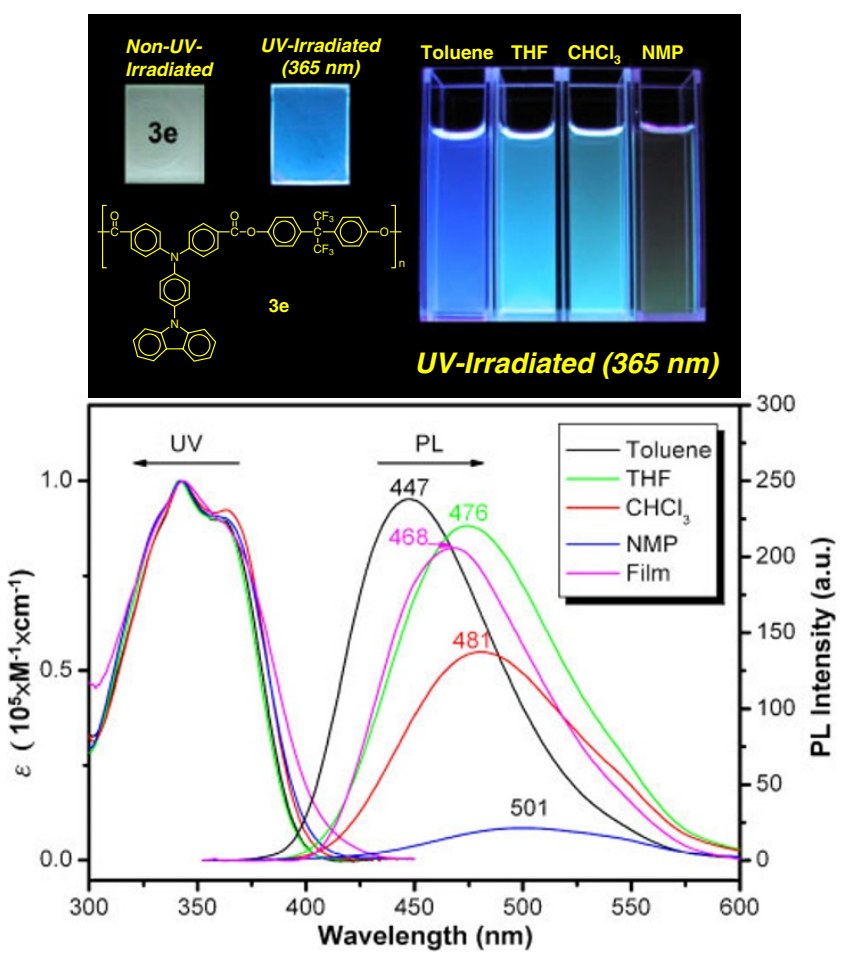

Figure 8. UV-Vis absorption and PL spectra of the solutions of polyarylate $3 \mathbf{e}$ in various solvents: $\mathrm{NMP}, \mathrm{CHCl}_{3}, \mathrm{THF}$, and Toluene at concentration $10^{-5} \mathrm{M}$, as well as its thin solid film. Photoluminescence of polyarylate $\mathbf{3 e}$ in various solvents $\left(10^{-5} \mathrm{M}\right)$ and thin films (thickness: $1-3 \mu \mathrm{m}$ ) by UV irradiation (Excited at $365 \mathrm{~nm})$.

Table V. Maxima of UV absorption $\left(\lambda_{\mathrm{abs}}\right)$, fluorescence $\left(\lambda_{\mathrm{PL}}\right)$, and quantum yield $\left(\Phi_{\mathrm{PL}}\right)$ for $\mathbf{3 e}$ in different solvents ${ }^{\mathrm{a}}$

\begin{tabular}{cccc}
\hline Solvent & $\begin{array}{c}\lambda_{\text {abs, max }} \\
(\mathrm{nm})\end{array}$ & $\begin{array}{c}\lambda_{\mathrm{PL}, \max } \\
(\mathrm{nm})^{\mathrm{b}}\end{array}$ & $\begin{array}{c}\Phi_{\mathrm{PL}} \\
(\%)^{\mathrm{c}}\end{array}$ \\
\hline Toluene & 342 & 447 & 21.9 \\
$\mathrm{THF}$ & 342 & 476 & 20.0 \\
$\mathrm{CHCl}_{3}$ & 343 & 481 & 12.9 \\
$\mathrm{NMP}$ & 342 & 501 & 2.4 \\
\hline
\end{tabular}

aPolymer concentration of $10^{-5} \mathrm{M}$ in different solvents. ${ }^{\mathrm{b}}$ They were excited at $\lambda_{\mathrm{abs}, \max }$ for solution state. ${ }^{\mathrm{c}}$ The quantum yield in dilute solution was calculated in an integrating sphere with quinine sulfate as the standard $\left(\Phi_{\mathrm{PL}}=0.546\right)$.

the electronic ground state. ${ }^{60}$ The fluorescence spectra of all the polyarylates in THF solutions exhibited emission maxima at $464-476 \mathrm{~nm}$ in the blue region with quantum yield $\left(\Phi_{\mathrm{PL}}\right)$ of $0.22-0.28$. The introduction of bulky TPA and carbazole units into the polymer main chain could effectively restrict intermolecular interactions and packing. Thus, the absorption and PL spectra of both solution and solid-state thin film of these polyarylates were similar to each other, with a strong blue-light emission upon exposure to UV irradiation. The UV-Vis transmission spectra of the polymers films are shown in Figure 9, and the cutoff 


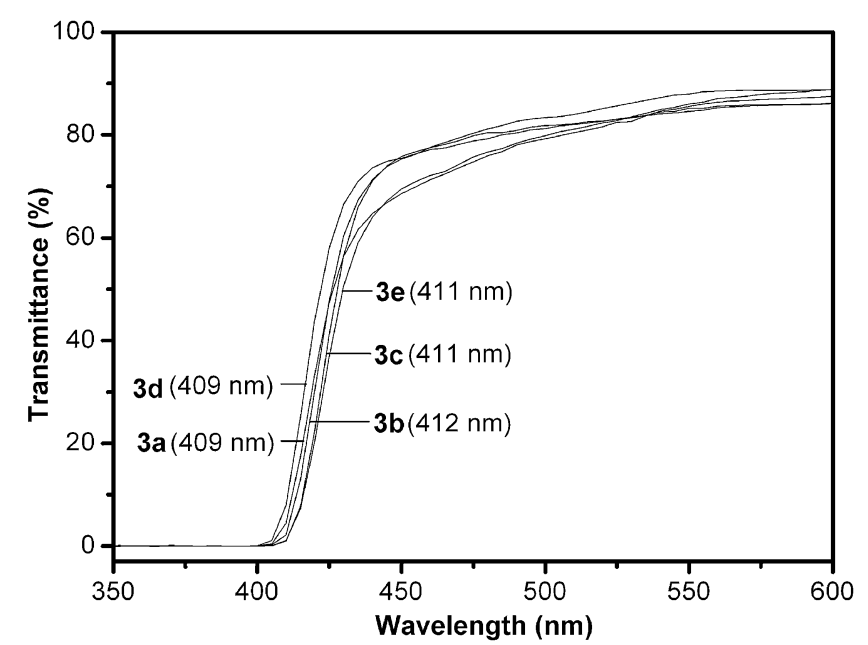

Figure 9. Transmission UV-visible absorption spectra of polyarylates films $(1-3 \mu \mathrm{m}$ in thickness).

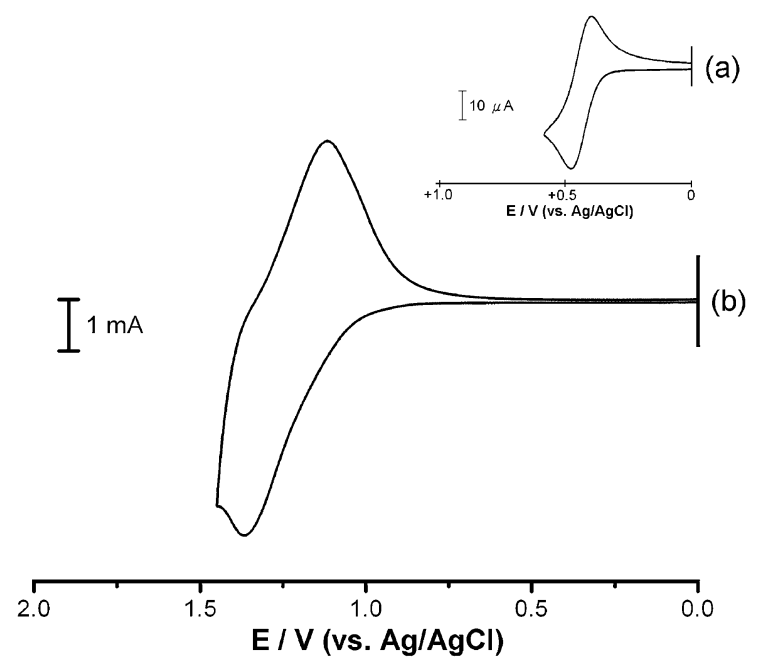

Figure 10. Cyclic voltammograms of (a) ferrocene and (b) the cast film of polyarylate $\mathbf{3 d}$ on an indium-tin oxide (ITO)-coated glass substrate in $\mathrm{CH}_{3} \mathrm{CN}$ containing $0.1 \mathrm{M}$ TBAP at a scan rate of $0.1 \mathrm{~V} / \mathrm{s}$.

wavelengths (absorption edge; $\lambda_{0}$ ) were recorded in the range of $409-412 \mathrm{~nm}$. It revealed that most of the polymers were light colored with high transparency in visible light region.

\section{Electrochemical Properties}

The electrochemical properties of the polyarylates were investigated by cyclic voltammetry conducted for the cast films on an ITO-coated glass substrate as working electrode in dry acetonitrile containing $0.1 \mathrm{M}$ of TBAP as an electrolyte under nitrogen atmosphere. The results are summarized in Table IV. The typical cyclic voltammogram for polyarylate $\mathbf{3 d}$ is shown in Figure 10. The first electron removal for polyarylate $\mathbf{3 d}$ is assumed to occur at the nitrogen atom on the main chain TPA unit, which is more elec- tron-rich than the nitrogen atom on the pendent carbazolyl moiety. Thus, the first stable cationic radical of polyarylates should be formed by the oxidation at the nitrogen atom of TPA moiety, and the second irreversible oxidation stage due to the carbazole group could be observed at higher applied potential. The energy of the HOMO and LUMO levels of the corresponding polyarylates can be determined from the oxidation onset potentials ( $\left.E_{\text {onset }}\right)$ and the onset absorption wavelength of the UV-Vis spectra, and the results are listed in Table IV. For example, the oxidation onset potential for polyarylate $\mathbf{3 d}$ has been determined as $1.00 \mathrm{~V} v s \mathrm{Ag} / \mathrm{AgCl}$. The external ferrocene/ferrocenium $\left(\mathrm{Fc} / \mathrm{Fc}^{+}\right)$redox standard $E_{1 / 2}$ is $0.48 \mathrm{~V}$ vs $\mathrm{Ag} /$ $\mathrm{AgCl}$ in $\mathrm{CH}_{3} \mathrm{CN}$. Assuming that the HOMO energy for the $\mathrm{Fc} / \mathrm{Fc}^{+}$standard is $4.80 \mathrm{eV}$ with respect to the zero vacuum level, the HOMO energy for polyarylate $3 d$ has been evaluated to be $5.32 \mathrm{eV}$. The high-lying HOMO energy level and reversible electrochemical oxidation of these polymers suggest that they have potential for use as hole-transporting materials in OLED devices.

\section{CONCLUSIONS}

Novel blue-light-emitting aromatic polyarylates having triphenylamine units in the main chain and carbazolyl pendent groups were successfully synthesized by direct polycondensation of the diacid monomer 4,4'-dicarboxy-4"'-( $N$-carbazolyl)triphenylamine with various aromatic diols. These amorphous polyarylates were readily soluble in common solvents and could be cast into flexible and transparent films with high $T_{\mathrm{g}}$ and thermal stability. All the polyarylates showed light color with high optical transparency and exhibited blue photoluminescence as films as well as in solution. Thus, these polyarylates can be considered not only as new candidates for easily processable highperformance polymeric materials but also could be applied to the blue-light-emitting materials and the source for generating of hybrid white light.

Acknowledgment. We are grateful to the National Science Council of the Republic of China for financial support of this work.

\section{REFERENCES}

1. H. H. Yang, "Aromatic High-Strength Fiber," Interscience, New York, 1989.

2. Y. Imai and M. Kakimoto, in "Handbook of Polymer Science and Technology. Vol. 1: Synthesis and Properties," N. P. Cheremisinoff, Ed., Dekker, New York, 1989, p. 177.

3. G. S. Liou, M. Kakimoto, and Y. Imai, J. Polym. Sci., Part A: Polym. Chem., 30, 2195 (1992). 
4. J. A. Mikroyannidis, J. Polym. Sci., Part A: Polym. Chem., 38, 2492 (2000).

5. C. P. Yang, G. S. Liou, R. S. Chen, and C. Y. Yang, J. Polym. Sci., Part A: Polym. Chem., 38, 1090 (2000).

6. S. H. Hsiao and H. W. Chiang, Eur. Polym. J., 40, 1691 (2004).

7. C. W. Tang and S. A. VanSlyke, Appl. Phys. Lett., 51, 913 (1987).

8. J. H. Burroughes, D. D. C. Bradley, A. R. Brown, R. N. Marks, K. Mackay, R. H. Friend, P. L. Burns, and A. B. Holmes, Nature, 347, 539 (1990).

9. A. Kraft, A. C. Grimsdale, and A. B. Holmes, Angew. Chem., Int. Ed., 37, 402 (1998).

10. R. H. Friend, R. W. Gymer, A. B. Holmes, J. H. Burroughes, R. N. Marks, C. Taliani, D. D. C. Bradley, D. A. Dos Santos, J. L. Bredas, M. Loglund, and W. R. Salaneck, Nature, 397, 121 (1999).

11. C. W. Tang, S. A. VanSlyke, and C. H. Chen, J. Appl. Phys., 85, 3610 (1989).

12. C. Adachi, K. Nagai, and Tamoto, Appl. Phys. Lett., 66, 2679 (1995).

13. Y. Shirota, J. Mater. Chem., 10, 1 (2000).

14. Y. Shirota, J. Mater. Chem., 15, 75 (2005).

15. E. Bellmann, S. E. Shaheen, S. Thayumannvan, S. Barlow, R. H. Grubbs, S. R. Marder, B. Kippelen, and N. Peyghambarian, Chem. Mater., 10, 1668 (1998).

16. E. Bellmann, S. E. Shaheen, R. H. Grubbs, S. R. Marder, B. Kippelen, and N. Peyghambarian, Chem. Mater., 11, 399 (1999).

17. J. Lu, A. R. Hlil, Y. Sun, A. S. Hay, T. Maindron, J. P. Dodelet, and M. D’Iorio, Chem. Mater., 11, 2501 (1999).

18. X. Wang, M. Nakao, K. Ogino, H. Sato, and H. Tan, Macromol. Chem. Phys., 202, 117 (2001).

19. X. Wang, Z. Chen, K. Ogino, H. Sato, K. Strzelec, S. Miyata, Y. J. Luo, and H. Tan, Macromol. Chem. Phys., 203, 739 (2002).

20. Q. Fang and T. Yamamoto, Macromolecules, 37, 5894 (2004)

21. H. Xiao, B. Leng, and H. Tian, Polymer, 46, 5707 (2005).

22. J. S. Cho, A. Kimoto, M. Higuchi, and K. Yamamoto, Macromol. Chem. Phys., 206, 635 (2005).

23. M. Sun, J. Li, B. Li, Y. Fu, and Z. Bo, Macromolecules, 38, 2651 (2005).

24. Y. Liu, M. S. Liu, X. C. Li, and A. K. Y. Jen, Chem. Mater., 10, 3301 (1998).

25. X. C. Li, Y. Liu, M. S. Liu, and A. K. Y. Jen, Chem. Mater., 11, 1568 (1999).

26. M. Redecker, D. D. C. Bradley, M. Inbasekaran, W. W. Wu, and E. P. Woo, Adv. Mater., 11, 241 (1999).

27. C. Ego, A. C. Grimsdale, F. Uckert, G. Yu, G. Srdanov, and K. Mullen, Adv. Mater., 14, 809 (2002).

28. C. F. Shu, R. Dodda, F. I. Wu, M. S. Liu, and A. K. Y. Jen, Macromolecules, 36, 6698 (2003).

29. F. I. Wu, P. I. Shih, C. F. Shu, Y. L. Tung, and Y. Chi, Macromolecules, 38, 9028 (2005).

30. Y. J. Pu, M. Soma, J. Kido, and H. Nishide, Chem. Mater., 13, 3817 (2001).

31. F. S. Liang, Y. J. Pu, T. Kurata, J. Kido, and H. Nishide,
Polymer, 46, 3767 (2005).

32. F. S. Liang, T. Kurata, H. Nishide, and J. Kido, J. Polym. Sci., Part A: Polym. Chem., 43, 5765 (2005).

33. T. Miteva, A. Meisel, W. Knoll, H. G. Nothofer, U. Scherf, D. C. Muller, K. Meerholz, A. Yasuda, and D. Neher, Adv. Mater., 13, 565 (2001).

34. Y. Fu, Y. Li, J. Li, S. Yan, and Z. Bo, Macromolecules, 37, 6395 (2004).

35. J. V. Grazulevicius, P. Strohriegl, J. Pielichowski, and K. Pielichowski, Prog. Polym. Sci., 28, 1297 (2003).

36. H. Sasabe, Supramol. Sci., 3, 91 (1996).

37. J. F. Morin and M. Leclerc, Macromolecules, 35, 8413 (2002).

38. Z. B. Zhang, M. Fujiki, H. Z. Tang, M. Motonaga, and K. Torimitsu, Macromolecules, 35, 1988 (2002).

39. G. Brizius, S. Kroth, and U. H. F. Bunz, Macromolecules, 35, 5317 (2002).

40. H. C. Kim, J. S. Kim, K. S. Kim, H. K. Park, S. Baek, and M. Ree, J. Polym. Sci., Part A: Polym. Chem., 42, 825 (2004).

41. J. Bouchard, M. Belletele, G. Durocher, and M. Leclerc, Macromolecules, 36, 4624 (2003).

42. K. L. Paik, N. S. Baek, and H. K. Kim, Macromolecules, 35, 6782 (2002).

43. F. Sanda, T. Kawaguchi, T. Masuda, and N. Kobayashi, Macromolecules, 36, 2224 (2003).

44. K. Kim, Y. R. Hong, S. W. Lee, J. I. Jin, Y. Park, B. H. Sohn, W. H. Kim, and J. K. Park, J. Mater. Chem., 11, 3023 (2001).

45. Y. Zhang, T. Wada, and H. Sasabe, J. Polym. Sci., Part A: Polym. Chem., 34, 2289 (1996).

46. Q. Wang, A. Gharvi, W. Li, and L. Yu, Polym. Prepr., (Am. Chem. Soc., Div. Polym. Chem.), 38, 516 (1997).

47. J. Jiang, C. Jiang, W. Yang, H. Zhen, F. Hung, and Y. Cao, Macromolecules, 38, 4072 (2005).

48. J. Huang, Y. Niu, W. Yang, Y. Mo, M. Yuan, and Y. Cao, Macromolecules, 35, 6080 (2002).

49. J. F. Morin and M. Leclerc, Macromolecules, 34, 4680 (2001).

50. C. J. Hawker and K. L. Wooley, Science, 309, 1200, (2005).

51. J. Gratt and R. E. Cohen, Macromolecules, 30, 3137 (1997).

52. J. Hwang, J. Sohn, and S. Y. Park, Macromolecules, 36, 7970 (2003).

53. S. H. Hsiao, C. W. Chen, and G. S. Liou, J. Polym. Sci., Part A: Polym. Chem., 42, 3302 (2004).

54. I. Mustonen, T. Hukka, and T. Pakkanen, Macromol. Rapid Commun., 21, 1286 (2000).

55. Z. Chen, Y. Liu, C. Zhang, and F. Bai, J. Appl. Polym. Sci., 92, 2777 (2004).

56. S. H. Cheng, S. H. Hsiao, T. H. Su, and G. S. Liou, Macromolecules, 38, 307 (2005).

57. G. S. Liou, S. H. Hsiao, and T. H. Su, J. Mater. Chem., 15, 1812 (2005).

58. G. S. Liou, S. H. Hsiao, N. K. Huang, and Y. L. Yang, Macromolecules, 39, 5337 (2006).

59. F. Higashi, M Ozawa, A. Hoshino, and A. Mochizuki, J. Polym. Sci., Polym. Chem. Ed., 23, 1699 (1985).

60. C. Reichardt, Chem. Rev., 94, 2319 (1994). 